\title{
Natronorubrum aibiense sp. nov., an extremely halophilic archaeon isolated from Aibi salt lake in Xin-Jiang, China, and emended description of the genus Natronorubrum
}

\author{
Heng-Lin Cui, ${ }^{1}, 2$ Dilbr Tohty, ${ }^{3}$ Jie Feng, ${ }^{1}$ Pei-Jin Zhou ${ }^{1}$ \\ and Shuang-Jiang Liu ${ }^{1}$ \\ ${ }^{1}$ State Key Laboratory of Microbial Resources, Institute of Microbiology, Chinese Academy of \\ Sciences, Beijing 100080, China \\ ${ }^{2}$ Graduate University of Chinese Academy of Sciences, Beijing 100049, China \\ ${ }^{3}$ College of Life Sciences, Xin-Jiang Normal University, Urumqi 830053, China
}

Correspondence

Shuang-Jiang Liu shuangjiang@hotmail.com
The genus Natronorubrum was established by $\mathrm{Xu}$ et al. (1999) to accommodate two novel species, Natronorubrum bangense and Natronorubrum tibetense. These two species were isolated from the Bange soda lake in Tibet, China, and are able to grow organotrophically under highly saline and alkaline conditions and at moderately high temperatures. Recently, it has been suggested that the genus Natronorubrum might also contain neutrophilic members that potentially have roles in heterotrophic oxidation of thiosulfate in hypersaline habitats (Sorokin et al., 2005). The highly saline lake Aibi $\left(82^{\circ} 35^{\prime}-83^{\circ} 16^{\prime} \mathrm{E} 44^{\circ} 05^{\prime}-45^{\circ} 08^{\prime}\right.$ $\mathrm{N}$ ) in Xin-Jiang, China, has been a long-term target for the study of element cycling and microbial flora under extremely high-salinity conditions (Cui et al., 2006), and many representative halophilic species have been described, such as Natrinema versiforme (Xin et al., 2000) and

Abbreviations: PG, phosphatidylglycerol; PGP, phosphatidylglycerol phosphate; TGD, triglycosyl diether.

The GenBank/EMBL/DDBJ accession number for the 16S rRNA gene sequence of strain $7-3^{\top}$ is DQ205516.

A one-dimensional thin-layer chromatogram of total polar lipids from strain $7-3^{\top}$ and related taxa is available as a supplementary figure in IJSEM Online.
Haloterrigena saccharevitans (Xu et al., 2005). Here we report the taxonomic characterization and identification of a halophilic archaeal organism.

Strains $7-3^{\mathrm{T}}, 7-1,7-2$, D7 and $\mathrm{ABH} 7$ were isolated from sediment of the Aibi salt lake. The medium and method used for isolation were as described by Xin et al. (2000) and Feng et al. (2004). The strains were routinely grown aerobically at $37^{\circ} \mathrm{C}$ in a complex medium containing the following (per litre distilled water): $7 \cdot 5 \mathrm{~g}$ Casamino acids (Difco), $10 \mathrm{~g}$ yeast extract (Difco), $3.0 \mathrm{~g}$ trisodium citrate, $10.2 \mathrm{~g}$ $\mathrm{MgCl}_{2} \cdot 6 \mathrm{H}_{2} \mathrm{O}, 20 \mathrm{~g} \mathrm{KCl}, 0.05 \mathrm{~g} \mathrm{FeSO}_{4} \cdot 7 \mathrm{H}_{2} \mathrm{O}, 180 \mathrm{~g} \mathrm{NaCl}$ ( $\mathrm{pH}$ adjusted to $8 \cdot 0$ with $1 \mathrm{M} \mathrm{NaOH}$ solution).

Phenotypic tests were performed according to the proposed minimal standards for the description of novel taxa in the order Halobacteriales (Oren et al., 1997). Colony morphology was observed on salt-milk agar medium (Kocur \& Hodgkiss, 1973) after incubation at $45^{\circ} \mathrm{C}$ for 6 days. Cell morphology was described and growth characteristic tests, miscellaneous biochemical tests, nutrition tests, sensitivity to antimicrobial agents, lipid analysis and nucleic acid characterization were performed as reported and cited by Feng et al. (2004, 2005). 
Table 1. Characteristics that differentiate Natronorubrum aibiense sp. nov. from the two other members of the genus

Strains: 1, Nrr. aibiense 7-3 $3^{\mathrm{T}}$ (strains 7-1, 7-2, D7 and ABH7 gave identical results); 2, Nrr. bangense $\mathrm{A} 33^{\mathrm{T}}$; 3, Nrr. tibetense GA33 ${ }^{\mathrm{T}}$. + , Positive; - , negative; ND, not determined. Data for reference strains were taken from $\mathrm{Xu}$ et al. (1999).

\begin{tabular}{|lccc|}
\hline Property & $\mathbf{1}$ & $\mathbf{2}$ & $\mathbf{3}$ \\
\hline Cell shape & Rod & Pleomorphic & Pleomorphic \\
Motility & + & - & - \\
$\mathrm{NaCl}$ concentration for growth (\%) & & & \\
$\quad$ Optimum & 18 & $22 \cdot 5$ & 20 \\
$\quad$ Range & $12-25$ & & $12-30$ \\
$\mathrm{Mg}^{2+}$ concentration for growth (M) & & $\mathrm{ND}$ & $\mathrm{ND}$ \\
$\quad$ Optimum & $0 \cdot 05$ & $\mathrm{ND}$ & $\mathrm{ND}$ \\
$\quad$ Range & $0-0 \cdot 5$ & $9 \cdot 5$ & $9 \cdot 0$ \\
pH for growth & & $8 \cdot 0-11 \cdot 0$ & $8 \cdot 5-11 \cdot 0$ \\
$\quad$ Optimum & $8 \cdot 0$ & - & - \\
$\quad$ Range & $6 \cdot 5-9 \cdot 5$ & - & + \\
Nitrate reduction & + & - & + \\
Hydrolysis of Tweens 40 and 60 & - & & + \\
Gelatin liquefaction & - & + & $60 \cdot 1$ \\
Sensitivity to: & - & $59 \cdot 9$ & + \\
$\quad$ Erythromycin & - & & \\
Tetracycline & $61 \cdot 2$ & & \\
DNA G+C content (mol\%) &
\end{tabular}

Cells of strains 7-3 $3^{\mathrm{T}}, 7-1,7-2, \mathrm{D} 7$ and $\mathrm{ABH} 7$ were rodshaped, motile, Gram-negative and able to grow over a wide range of salinities (12-25\% salt; optimal growth at $18 \%$ ). Cells lysed in distilled water. Colonies on salt-milk agar medium were red-pigmented. Results of phenotypic tests and nutritional features of these strains are given in the species description below and in Table 1. As listed in Table 1, the strains had very similar phenotypic properties. Minor differences among the strains were that strains 7-1, 7-2, D7 and ABH7 produced smaller colonies on complex medium than strain $7-3^{\mathrm{T}}$, and that strain $7-3^{\mathrm{T}}$ grew faster than the others.

The nearly entire $16 \mathrm{~S}$ rRNA genes of strains $7-3^{\mathrm{T}}, 7-1,7-2$, D7 and ABH7 were PCR-amplified and the sequences were used for construction of a phylogenetic tree (Fig. 1). Sequence similarity calculations using Kimura's twoparameter and pairwise-deletion model gave values of 99.7-99.9\%, indicating that strains $7-3^{\mathrm{T}}, 7-1,7-2$, D7 and $\mathrm{ABH} 7$ represented a monophyletic group. The most closely related species were Nrr. bangense and Nrr. tibetense, with 16S rRNA gene sequence similarities of $95 \cdot 2$ and $97 \cdot 0 \%$, respectively. Levels of DNA-DNA relatedness between strain $7-3^{\mathrm{T}}$ and Nrr. bangense $\mathrm{A} 33^{\mathrm{T}}$ and Nrr. tibetense $\mathrm{GA}_{3} 3^{\mathrm{T}}$ were 45 and $37 \%$, respectively. The DNA G+C content of strain $7-3^{\mathrm{T}}$ was $61 \cdot 2 \mathrm{~mol} \%$.

The phospholipids of strain $7-3^{\mathrm{T}}, N r r$. bangense $\mathrm{A} 33^{\mathrm{T}}$ and Nrr. tibetense $\mathrm{GA} 33^{\mathrm{T}}$ were determined to be $\mathrm{C}_{20}-\mathrm{C}_{20}$ and $\mathrm{C}_{20}-\mathrm{C}_{25}$ derivatives of phosphatidylglycerol (PG) and

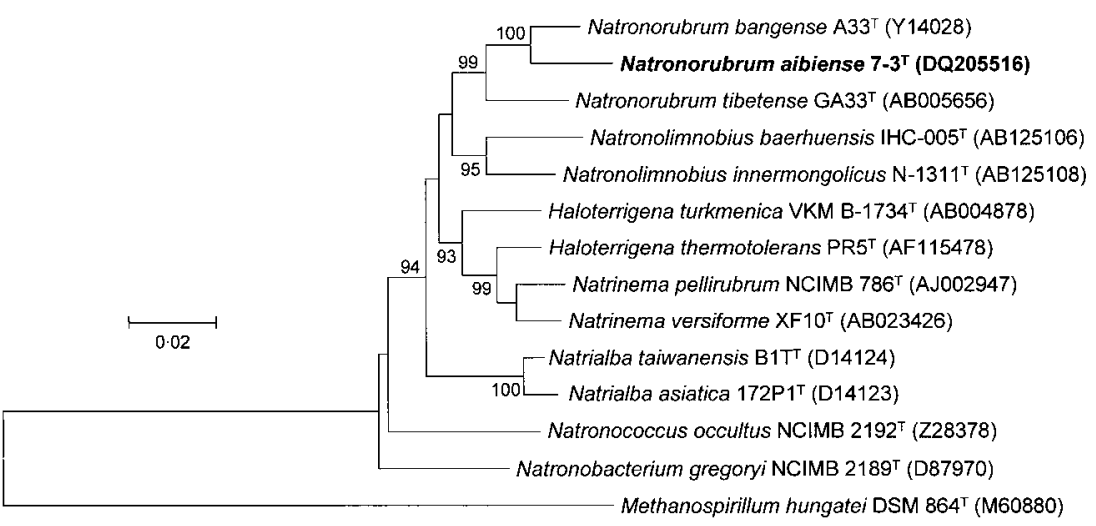

Fig. 1. Phylogenetic tree based on $16 \mathrm{~S}$ rRNA gene sequences showing the relationship between members of the genus Natronorubrum and related genera within the family Halobacteriaceae. Bootstrap values are based on 1000 replicates; only values $>80 \%$ are shown. Bar, 0.02 expected changes per site. 
phosphatidylglycerol phosphate (PGP) methyl ester. In addition, three glycolipids, namely triglycosyl diether-1 (TGD-1) and unidentified glycolipids 1 and 2, were detected for strain $7-3^{\mathrm{T}}$, by comparison with the glycolipid profile of Halobacterium salinarum ATCC 33170 (Torreblanca et al., 1986), but these were not detected for Nrr. bangense $\mathrm{A} 33^{\mathrm{T}}$ or Nrr. tibetense GA33 ${ }^{\mathrm{T}}$ (see Supplementary Fig. S1 in IJSEM Online).

Based on these results it is concluded that strain $7-3^{\mathrm{T}}$ represents a novel species of the genus Natronorubrum, for which the name Natronorubrum aibiense sp. nov. is proposed.

\section{Emended description of the genus Natronorubrum Xu et al. 1999}

Cells are Gram-negative, rod-shaped or pleomorphic flatshaped (triangular, square, disc and other polygonal shapes). Colonies are red-pigmented. Cells are non-motile or motile, strictly aerobic, oxidase- and catalase-positive. Require at least $12 \% \mathrm{NaCl}$ for growth; cells are lysed in distilled water. Alkaliphilic or neutrophilic. Mesophilic and chemoorganotrophic. Many sugars (glucose, fructose, sucrose, maltose and lactose) are utilized, sometimes with acid production. Polar lipids are $\mathrm{C}_{20}-\mathrm{C}_{20}$ and $\mathrm{C}_{20}-\mathrm{C}_{25}$ derivatives of PG and PGP. Cells may also contain TGD-1 and other unidentified glycolipids. The type species is Natronorubrum bangense.

\section{Description of Natronorubrum aibiense sp. nov.}

Natronorubrum aibiense (ai.bi.en'se. N.L. neut. adj. aibiense from Aibi salt lake, China).

Cells are rod-shaped $(0 \cdot 8-1 \cdot 0 \times 1 \cdot 4-3.6 \mu \mathrm{m})$ and Gramnegative. Colonies on salt-milk agar plates containing $18 \%(\mathrm{w} / \mathrm{v}) \mathrm{NaCl}$ are red, elevated and round. Chemoorganotrophic and aerobic. Growth occurs at $\mathrm{NaCl}$ concentrations of $2 \cdot 0-4 \cdot 3 \mathrm{M}$, at $\mathrm{pH} 6 \cdot 5-9 \cdot 5$ and at $20-50{ }^{\circ} \mathrm{C}$. Optimal $\mathrm{NaCl}$ concentration, $\mathrm{pH}$ and temperature for growth are $2 \cdot 6-3 \cdot 1 \mathrm{M}, \mathrm{pH} 8.0$ and $45^{\circ} \mathrm{C}$, respectively. Catalase- and oxidase-positive. Anaerobic growth with nitrate, arginine or DMSO does not occur. Nitrate reduction to nitrite is observed. $\mathrm{H}_{2} \mathrm{~S}$ is not produced from $\mathrm{Na}_{2} \mathrm{~S}_{2} \mathrm{O}_{3}$. Indole formation is positive. Tween 80 , casein and starch are not hydrolysed. Gelatin is not liquefied. Casamino acids are required for growth. Glucose, galactose, sucrose and maltose are utilized and acids are produced. No growth or acid production is observed on fructose, sorbose, xylose, mannose, lactose, D-ribose, mannitol or sorbitol. Sensitive to rifampicin and novobiocin. Resistant to erythromycin, neomycin, chloramphenicol, bacitracin, ampicillin, penicillin G, norfloxacin, ciprofloxacin, streptomycin, kanamycin, tetracycline and vancomycin. Cells contain $\mathrm{C}_{20}-\mathrm{C}_{20}$ and $\mathrm{C}_{20}-\mathrm{C}_{25}$ derivatives of PG and PGP, TGD-1 and two unidentified glycolipids. The DNA G $+\mathrm{C}$ content of the type strain is $61 \cdot 2 \mathrm{~mol} \%\left(T_{\mathrm{m}}\right)$.

The type strain, $7-3^{\mathrm{T}}\left(=\right.$ CGMCC $\left.1.4299^{\mathrm{T}}=\mathrm{JCM} 13488^{\mathrm{T}}\right)$, was isolated from Aibi salt lake in Xin-Jiang, China.

\section{Acknowledgements}

This work was supported by grants from the Ministry of Science and Technology (2004CB719601) and Chinese Academy of Sciences (KJCX1-SW-07).

\section{References}

Cui, H.-L., Yang, Y., Tohty, D., Zhou, P.-J. \& Liu, S.-J. (2006). Biodiversity of halophilic archaea isolated from two salt lakes in Xin-Jiang region of China. Acta Microbiol Sin 46, 171-175.

Feng, J., Zhou, P. \& Liu, S.-J. (2004). Halorubrum xinjiangense sp. nov., a novel halophile isolated from saline lakes in China. Int J Syst Evol Microbiol 54, 1789-1791.

Feng, J., Zhou, P., Liu, S.-J. \& Warren-Rhodes, K. (2005). Halorubrum alkaliphilum sp. nov., a novel haloalkaliphile isolated from a soda lake in Xinjiang, China. Int J Syst Evol Microbiol 55, 149-152.

Kocur, M. \& Hodgkiss, W. (1973). Taxonomic status of the genus Halococcus Schoop. Int J Syst Bacteriol 23, 151-156.

Oren, A., Ventosa, A. \& Grant, W. D. (1997). Proposal of minimal standards for the description of new taxa in the order Halobacteriales. Int J Syst Bacteriol 47, 233-238.

Sorokin, D. Y., Tourova, T. P. \& Muyzer, G. (2005). Oxidation of thiosulfate to tetrathionate by a haloarchaeon isolated from hypersaline habitat. Extremophiles 9, 501-504.

Torreblanca, M., Rodriguez-Valera, F., Juez, G., Ventosa, A., Kamekura, M. \& Kates, M. (1986). Classification of nonalkaliphilic halobacteria based on numerical taxonomy and polar lipid composition, and description of Haloarcula gen. nov. and Haloferax gen. nov. Syst Appl Microbiol 8, 89-99.

Xin, H., Itoh, T., Zhou, P., Suzuki, K., Kamekura, M. \& Nakase, T. (2000). Natrinema versiforme sp. nov., an extremely halophilic archaeon from Aibi salt lake, Xinjiang, China. Int J Syst Evol Microbiol 50, 1297-1303.

Xu, Y., Zhou, P. \& Tian, X. (1999). Characterization of two novel haloalkaliphilic archaea Natronorubrum bangense gen. nov., sp. nov. and Natronorubrum tibetense gen. nov., sp. nov. Int J Syst Bacteriol 49, 261-266.

Xu, X., Liu, S., Tohty, D., Oren, A., Wu, M. \& Zhou, P. (2005). Haloterrigena saccharevitans sp. nov., an extremely halophilic archaeon from Xin-Jiang, China. Int J Syst Evol Microbiol 55, 2539-2542. 